\title{
Lunar Surface Habitat Configuration Assessment: Methodology and Observations
}

\author{
Amanda Carpenter \\ Jacobs Technology ESC, NASA JSC, Houston, TX 77058 USA, \\ amanda.carpenter-1@nasa.gov
}

\begin{abstract}
The Lunar Habitat Configuration Assessment evaluated the major habitat approaches that were conceptually developed during the Lunar Architecture Team II Study. The objective of the configuration assessment was to identify desired features, operational considerations, and risks to derive habitat requirements. This assessment only considered operations pertaining to the lunar surface and did not consider all habitat conceptual designs developed.

To examine multiple architectures, the Habitation Focus Element Team defined several adequate concepts which warranted the need for a method to assess the various configurations. The fundamental requirement designed into each concept included the functional and operational capability to support a crew of four on a six-month lunar surface mission; however, other conceptual aspects were diverse in comparison.

The methodology utilized for this assessment consisted of defining figure of merits, providing relevant information, and establishing a scoring system. In summary, the assessment considered the geometric configuration of each concept to determine the complexity of unloading, handling, mobility, leveling, aligning, mating to other elements, and the accessibility to the lunar surface.

In theory, the assessment was designed to derive habitat requirements, potential technology development needs and identify risks associated with living and working on the lunar surface. Although the results were more subjective opposed to objective, the assessment provided insightful observations for further assessments and trade studies of lunar surface habitats. This overall methodology and resulting observations will be describe in detail and illustrative examples will be discussed.
\end{abstract}

\section{Introduction}

The Lunar Architecture Team II, Habitation Focus Element was challenged to conceptually develop a Lunar Habitat with a set of minimal constraints and a vast amount of creativity. Throughout the conceptual design process many viable concepts were introduced which warrant a process to identify desired features, operational considerations and risks to drive habitat requirements. 
This paper provides an overview of the work performed, as well as the figure of merits defined and the data gathered to produce a valuable assessment of the different geometric shapes and configuration of lunar habitats. This assessment only considered operations pertaining to the lunar surface. In the following we will consider just a few of the many conceptual designs developed during the Lunar Architecture Team II Study.

\section{Lunar Surface Habitat Configuration}

One element required for a successful lunar mission is an optimal, effective habitat to lend to five key functions consisting of the following: crew operations, EVA, medical operations, science, and mission operations. The conceptual habitat designs, shown in Table 1, were developed based on minimal constraints, ground rules and assumptions. The underlining ground rule and assumption defined for this study was the habitat should provide capability to sustain 4 crew for 180 day mission. The habitat was constrained to a 10 meter shroud and required to be compatible with the Lander configuration. These limitations provided a basis for developing the concepts described in Table 1. Majority of these properties were not available at the beginning of this assessment, but as a result of the assessment they came to fruition. For example, the habitat configuration for Option $2 \& 6$ originally was assessed with four elements, but through the first iteration, it became apparent that volume per crew member was not adequate, comparative to the recommendations based on volumetric assessment provided as a result of this effort.

\begin{tabular}{|c|c|c|c|c|c|}
\hline & 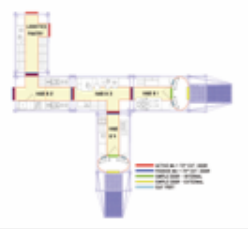 & 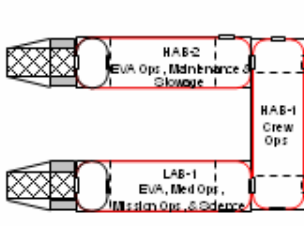 & 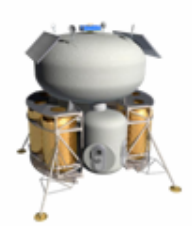 & $(0)$ & \\
\hline Parameter & $\begin{array}{c}\text { Option } 2 \text { \& } 6 \\
3 \times 5 \text { mini-Habs } \\
\text { Al-Li Hard Shell }\end{array}$ & $\begin{array}{c}\underline{\text { Option 2 }} \\
3 \times 10 \text { (deployed) } \\
\text { Hybrid Hab } \\
\text { Mid Section Expandable }\end{array}$ & $\begin{array}{l}\text { Option 3 } \\
\text { Concept \#1 } \\
\text { Monolithic } \\
\text { Habitat }\end{array}$ & $\begin{array}{l}\text { Option } 3 \\
\text { Concep t \#2 } \\
\text { Monolithic } \\
\text { Habitat }\end{array}$ & $\frac{\text { Option 4 }}{\text { Mobile Habitat }}$ \\
\hline \# of Elements & 5 & 3 & 1 & $\mathbf{l}$ & 3 \\
\hline $\begin{array}{l}\text { Pressurized } \\
\text { Volume }\end{array}$ & $137 \mathrm{~m}^{3}$ & $189 \mathrm{~m}^{3}$ & $198 \mathrm{~m}^{3}$ & $154 \mathrm{~m}^{3}$ & $165 \mathrm{~m}^{3}$ \\
\hline $\begin{array}{l}\text { Floor } \\
\text { Area }\end{array}$ & $\begin{array}{c}\sim 2 \mathrm{~m} \times 4.75 \mathrm{~m} \\
=95 \mathrm{~m}^{2} \\
\text { Total of } 5=475 \mathrm{~m}^{2}\end{array}$ & $\begin{array}{c}\sim 2 \mathrm{~m} \times 9.75 \mathrm{~m}=195 \mathrm{~m}^{2} \\
\text { Total of } 3=97.5 \mathrm{~m}^{2}\end{array}$ & $41.17 \mathrm{~m}^{2}$ & $33.45 \mathrm{~m}^{2}$ & $\begin{array}{l}3 \mathrm{~m} \times 85 \mathrm{~m} \\
=255 \mathrm{~m}^{2} \\
\text { Total of } 3 \\
=765 \mathrm{~m}^{2}\end{array}$ \\
\hline Mass & 5 units $=20375 \mathrm{~kg}$ & 3 units $=18384 \mathrm{~kg}$ & $12975 \mathrm{~kg}$ & $12280 \mathrm{~kg}$ & \\
\hline Power & $12.4 \mathrm{~kW}$ & $12.6 \mathrm{~kW}$ & $10.3 \mathrm{~kW}$ & $10.3 \mathrm{~kW}$ & $9.8 \mathrm{~kW}$ \\
\hline $\begin{array}{l}\text { \# of Available } \\
\text { Ports }\end{array}$ & 3 & 4 & 3 & 2 & 2 \\
\hline Outfitting & Pre-Integrated & Some Outfitting Required & $\begin{array}{l}\text { Some Ouffitting } \\
\text { Required }\end{array}$ & $\begin{array}{c}\text { Some } \\
\text { Outfitting } \\
\text { Required }\end{array}$ & \\
\hline
\end{tabular}

Table 1. Lunar Surface Habitat Configuration \& Data. 


\section{Methodology}

The methodology utilized for this assessment commenced with the definition of quantitative figure of merits, providing relevant data, and establishing a scoring system. Defining figure of merit (FOM) for this assessment was an iterative process and the quantification of acceptable FOM for comprehensive evaluation requires further effort. The first cycle endeavored resulted in a vast selection of FOMs with majority producing subjective results based on minimal or, in some cases, no previous data points. The basis for subjective views was due to limited data available at the beginning of this process. Several iteration occurred to develop a more objective means for assess the numerous lunar surface outpost configurations, and per this assessment definition, lunar surface habitat desired features, operational considerations, and risk to drive habitat requirements were captured. Figure 1 depicts the iterative progression of how the inputs were utilized for this assessment and the outputs were communicated for further consideration. This is not a complete system and for further FOM definition additional effort must occur. The major FOM considerations are shown in Tables 2 and 3.

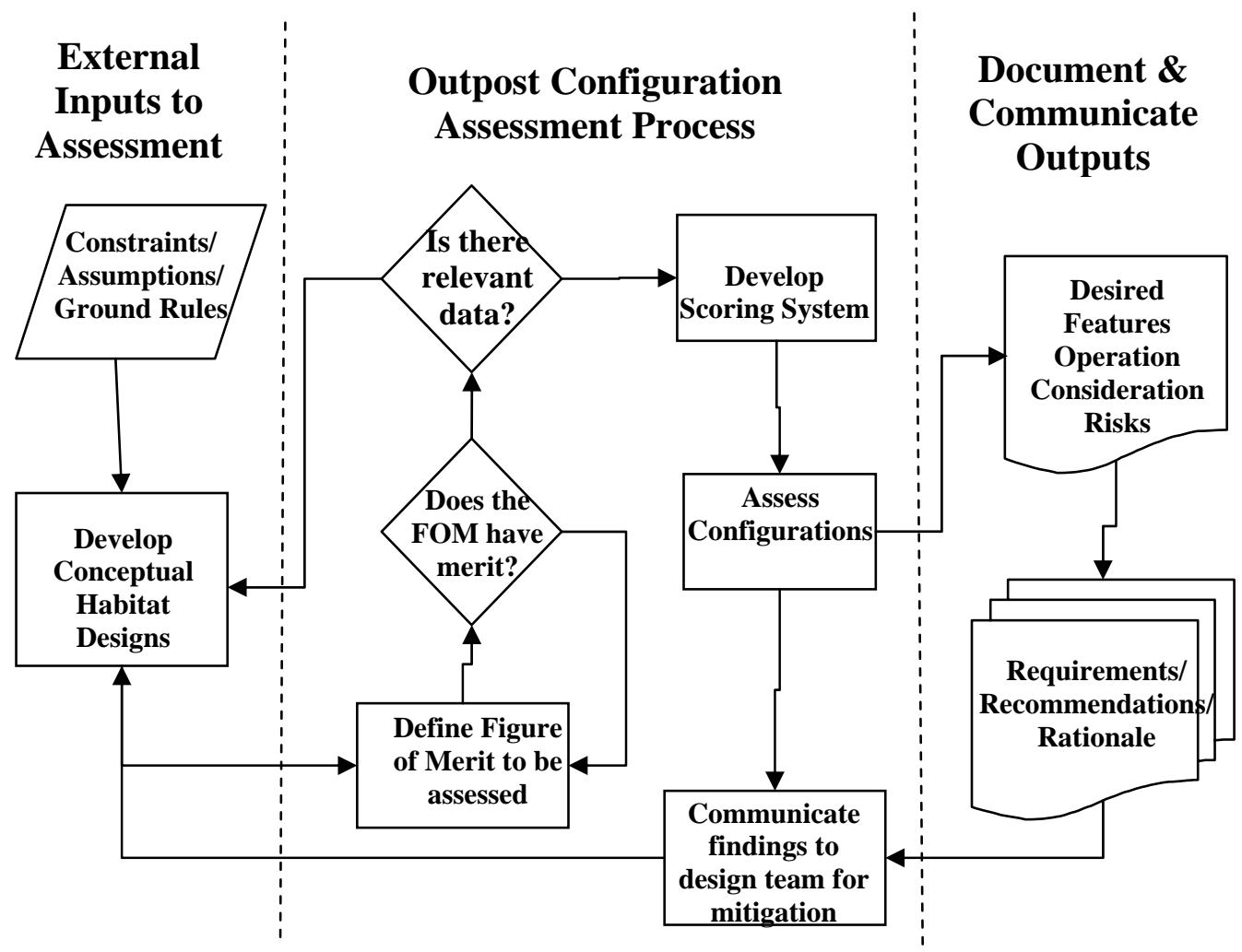

Figure 1. Methodology for Lunar Surface Habitat Configuration Assessment 
The geometrical shape and dimension along with mass and volume properties proved to be a valuable input for this assessment. The geometrical configuration and various dimensions of each conceptual habitat design provided the parametric data to characterize the relationship between habitat concepts to the recommended volume required for habitability. Habitat dimension provided a total pressurized volume for each concept enabling a comparative assessment between volume and mass properties extracted from the Master Equipment List (MEL). This provided an analysis of the mass to volume ratio for achieve a desired relation to potentially minimize costs. Obliviously, the optimal solution is to produce a lower ratio, but mass/volume ratio is not the sole factor for determining the best habitat configuration. For this assessment, the mass $(\mathrm{kg}) /$ volume $\left(\mathrm{m}^{3}\right)$ ratio ranged between 75.4 to 163.5 , but for better results other consideration are required including usable volume, habitable volume and the floor area. The data can be viewed in Table 3.

\begin{tabular}{|c|c|c|c|c|c|}
\hline \multirow[t]{2}{*}{ Figure of Merit } & \multirow{2}{*}{$\begin{array}{c}\text { Requirement/ } \\
\text { Recommendation }\end{array}$} & \multirow[t]{2}{*}{ Merit } & \multicolumn{3}{|c|}{ Rating } \\
\hline & & & 1 & 5 & 9 \\
\hline Habitat Dimension & $10 \mathrm{~m}$ shroud & $\begin{array}{l}\text { Shroud } \\
\text { compatible }\end{array}$ & $\begin{array}{l}\text { Doesn't } \\
\text { meet req. }\end{array}$ & $\begin{array}{l}\text { Meets } \\
\text { req. }\end{array}$ & $\begin{array}{l}\text { Exceeds } \\
\text { req. }\end{array}$ \\
\hline $\begin{array}{l}\text { Pressurized volume } \\
\left(\mathbf{m}^{3}\right) \text { at outpost } \\
\text { steady state }\end{array}$ & $\begin{array}{l}>30 \mathrm{~m}^{3} \text { per crew (min. total } \\
\left.\text { volume } 126 \mathrm{~m}^{3}\right)_{1}\end{array}$ & $\begin{array}{l}\text { More is } \\
\text { better }\end{array}$ & $\begin{array}{l}\text { Doesn't } \\
\text { meet req. }\end{array}$ & $\begin{array}{l}\text { Meets } \\
\text { req. }\end{array}$ & $\begin{array}{l}\text { Exceeds } \\
\text { req. }\end{array}$ \\
\hline $\begin{array}{l}\text { Habitable Volume } \\
\left(\mathrm{m}^{3}\right) \text { at outpost } \\
\text { steady state }\end{array}$ & $\begin{array}{l}19 \mathrm{~m}^{3} \text { (based of 0g ISS); data } \\
\text { was calculated using the } 40 / 60 \\
\% \text { formula }_{1}\end{array}$ & $\begin{array}{l}\text { More is } \\
\text { better }\end{array}$ & $\begin{array}{l}\text { Doesn't } \\
\text { meet req. }\end{array}$ & $\begin{array}{l}\text { Meets } \\
\text { req. }\end{array}$ & $\begin{array}{l}\text { Exceeds } \\
\text { req. }\end{array}$ \\
\hline $\begin{array}{l}\text { Mass per Volume } \\
\left(\mathrm{kg} / \mathrm{m}^{3}\right)\end{array}$ & Higher ratio will increase cost & $\begin{array}{l}\text { Less is } \\
\text { better }\end{array}$ & High & $\begin{array}{l}\text { Mid- } \\
\text { range }\end{array}$ & Low \\
\hline Mass per Landing & $<16000 \mathrm{MT}$ & $\begin{array}{l}\text { Less is } \\
\text { better }\end{array}$ & $\begin{array}{l}\text { Doesn't } \\
\text { meet req. }\end{array}$ & $\begin{array}{l}\text { Meets } \\
\text { req. }\end{array}$ & $\begin{array}{l}\text { Exceeds } \\
\text { req. }\end{array}$ \\
\hline
\end{tabular}

${ }_{1}$ This requirement/recommendation was provided prior to the volumetric assessment completed by the Habitation Focus Element.

Table 2. Mass and Volume Assessment Criteria.

The FOM identified for this assessment considered the surface operations to achieve outpost steady state, and for this purpose steady state refers to the point when the system is operating at full capability also referred to initial operating capability (IOC). These FOMs are listed in Table 3, along with rationale, merit and rating system. The major driver for the defined assessment criteria, considered the habitat could potentially be removed from the Lander; consequently, certain surface operations are necessary to achieve IOC. The assessment considered the geometric configuration of each concept to determine the complexity of unloading, handling, mobility, leveling, aligning, mating to other elements, and the accessibility to the lunar surface.

Other considerations defined were scalability, versatility, extensibility, and technology readiness. For this assessment, scalability was defined as the potential for outpost growth by adding additional volume for functional areas on the subject of science, med ops, crew quarters, etc. The FOM was based on the addition opportunities and ease to add modules 
to the outpost, for example if additional ports were available beyond the minimal requirement, the response was positive.

Versatility was also considered for the vast changes during the architecture definition phase and for compatibility with the various Lander configurations which potentially might drive sortie missions. Versatility allows the habitat to adapt to various surface architectures including a range of potential landing site locations based on the campaign analysis. The ability to reduce mass, costs, and risk by delivering segments is desired. In addition to versatility, subjectively, extensibility was a topic of interests' bases on whether the habitat configuration assessed could become compatible with a crew transfer vehicle for Mars expeditions.

\begin{tabular}{|c|c|c|c|c|c|}
\hline \multirow[t]{2}{*}{ Figure of Merit } & \multirow{2}{*}{$\begin{array}{c}\text { Requirement/ } \\
\text { Recommendation/ } \\
\text { Rationale }\end{array}$} & \multirow[t]{2}{*}{ Merit } & \multicolumn{3}{|c|}{ Rating } \\
\hline & & & 1 & 5 & 9 \\
\hline Total \# of missions to achieve IOC & $\begin{array}{l}\text { C-crew missions; } \\
\text { CA- cargo missions }\end{array}$ & $\begin{array}{l}\text { Less is better; } \\
\text { reduce cost }\end{array}$ & $1-2$ & $2-3$ & $>3$ \\
\hline $\begin{array}{l}\text { Unloading: time required, \# of } \\
\text { operations, complexity of ops }\end{array}$ & $\begin{array}{l}\text { \# of modules delivered would } \\
\text { increase time, \# ops, and } \\
\text { complexity }\end{array}$ & Less is better & $1-2$ & $2-3$ & $>3$ \\
\hline $\begin{array}{l}\text { Handling: time required, \# of } \\
\text { operations, complexity of ops }\end{array}$ & $\begin{array}{l}\text { \# of modules delivered would } \\
\text { increase time, \# ops, and } \\
\text { complexity }\end{array}$ & Less is better & $1-2$ & $2-3$ & $>3$ \\
\hline $\begin{array}{l}\text { Mobility: time required, \# of } \\
\text { operations, complexity of ops }\end{array}$ & $\begin{array}{l}\text { \# of modules delivered would } \\
\text { increase time, \# ops, and } \\
\text { complexity }\end{array}$ & Less is better & $1-2$ & $2-3$ & $>3$ \\
\hline $\begin{array}{l}\text { Leveling: time required, \# of } \\
\text { operations, complexity of ops }\end{array}$ & $\begin{array}{l}\text { \# of modules delivered would } \\
\text { increase time, \# ops, and } \\
\text { complexity }\end{array}$ & Less is better & $1-2$ & $2-3$ & $>3$ \\
\hline $\begin{array}{l}\text { Alignment: time required, \# of } \\
\text { operations, complexity of ops }\end{array}$ & $\begin{array}{l}\text { \# of modules delivered would } \\
\text { increase time, \# ops, and } \\
\text { complexity }\end{array}$ & Less is better & $1-2$ & $2-3$ & $>3$ \\
\hline $\begin{array}{l}\text { Mating/Connection of Elements: } \\
\text { time required, \# of operations, } \\
\text { complexity of ops }\end{array}$ & $\begin{array}{l}\text { \# of modules delivered would } \\
\text { increase time, \# ops, and } \\
\text { complexity }\end{array}$ & Less is better & $1-2$ & $2-3$ & $>3$ \\
\hline $\begin{array}{l}\text { Mating/Connection of Umbilical: } \\
\text { time required, \# of operations, } \\
\text { complexity of ops }\end{array}$ & $\begin{array}{l}\text { \# of modules delivered would } \\
\text { increase time, \# ops, and } \\
\text { complexity }\end{array}$ & Less is better & $1-2$ & $2-3$ & $>3$ \\
\hline
\end{tabular}

Table 3. Surface Operations to Achieve IOC Assessment Criteria.

\section{Habitat Properties}

Habitat properties and the necessary data to assess the various lunar surface habitats are displayed in Table 4. This information was gathered during this process and provided a measure to objectively assess each option. Table 4 along with further data is required for comprehensive results, but for the intention of this assessment the data capture provided valuable outputs. 


\begin{tabular}{|c|c|c|c|c|c|c|c|c|c|c|}
\hline & $\begin{array}{l}4 \text { min- } \\
\text { habs w/ } \\
\text { aluminu } \\
\text { m hard } \\
\text { shell }\end{array}$ & $\begin{array}{l}2 \text { hard-shell } \\
\text { (aluminum) } \\
\text { mini habs } \\
\& 2 \\
\text { expandable }\end{array}$ & $\begin{array}{l}4 \text { mini } \\
\text { habs with } \\
\text { composit } \\
\text { e hard } \\
\text { shells }\end{array}$ & $\begin{array}{l}2 \text { hard-shell } \\
\text { (composite) } \\
\text { mini-habs } \\
\& 2 \\
\text { expandable }\end{array}$ & $\begin{array}{l}3 \\
\text { exp. } \\
\text { mini } \\
- \\
\text { habs }\end{array}$ & $\begin{array}{l}\text { Monolithi } \\
\text { c A }(7.5 \mathrm{~m} \\
\text { x } 7.6 \mathrm{~m})\end{array}$ & $\begin{array}{l}\text { Monolithi } \\
\text { c B }(7.5 \mathrm{~m} \\
\text { x } 10.43 \mathrm{~m})\end{array}$ & Torus & $\begin{array}{l}\text { Mod. } \\
\text { Torus }\end{array}$ & $\begin{array}{l}2 \\
\text { expandabl } \\
\text { e mini- } \\
\text { habs }\end{array}$ \\
\hline $\begin{array}{l}\text { \# of elements } \\
\text { \& Dimensions } \\
\text { (m) of each } \\
\text { element }\end{array}$ & $\begin{array}{l}4: 3 \mathrm{~m} \mathrm{x} \\
3 \mathrm{~m} \times 5 \mathrm{~m}\end{array}$ & $\begin{array}{l}\text { 2- HS 3m } \\
\text { x3m x5m } \\
2- \\
\text { expand.3m } \\
\text { x 3m x } \\
10 m\end{array}$ & $\begin{array}{l}4-3 m \times \\
3 m \times 5 m\end{array}$ & $\begin{array}{l}\text { 2- HS 3m } \\
\text { x3m x5m } \\
2- \\
\text { expand.3m } \\
\text { x 3m x 10m }\end{array}$ & $\begin{array}{l}3- \\
3 \mathrm{mx} \\
3 \mathrm{mx} \\
10 \mathrm{~m}\end{array}$ & $\begin{array}{l}\text { Diameter- } \\
7.5 \mathrm{~m} \\
\text { ht.-7.6 }\end{array}$ & $\begin{array}{l}\text { Diameter- } \\
7.5 \mathrm{~m} \\
\text { ht.-10.43 }\end{array}$ & $\begin{array}{l}\text { Dia.- } \\
12.5 \mathrm{~m} \\
, \\
\text { ht.- } \\
2.5 \mathrm{~m}\end{array}$ & $\begin{array}{l}\text { dia.- } \\
12.5 \mathrm{~m} \text {, } \\
\text { ht.- } \\
2.5 \mathrm{~m} \text {, } \\
\text { Center } \\
\text { cap- } \\
19 \mathrm{~m}\end{array}$ & $\begin{array}{l}2-3 m x \\
3 m \times 3 m\end{array}$ \\
\hline $\begin{array}{l}\text { Total vol. }\left(\mathrm{m}^{3}\right) \\
\text { @ IOC }\end{array}$ & 109.8 & 182 & 109.8 & 182 & 189 & 230 & 327 & 340 & 459 & 126 \\
\hline $\begin{array}{l}\text { Habitable vol. } \\
\left(\mathrm{m}^{3}\right) @ \text { IOC }\end{array}$ & 65.9 & 109.2 & 65.9 & 109.2 & $\begin{array}{l}113 . \\
4\end{array}$ & 138 & 192.2 & 204 & 215.4 & 75.6 \\
\hline $\begin{array}{l}\text { Private } \\
\text { vol./crew }\left(\mathrm{m}^{3}\right)\end{array}$ & 2.5 & 5 & 2.5 & 5 & 5 & 6.17 & 10.29 & TBD & TBD & TBD \\
\hline $\begin{array}{l}\text { Mass (kg)@ } \\
\text { IOC }\end{array}$ & 17947 & 22670 & 17612 & 23316 & TBD & 23708 & 24665 & TBD & TBD & TBD \\
\hline $\begin{array}{l}\text { Mass/Vol. } \\
\left(\mathrm{kg} / \mathrm{m}^{3}\right)\end{array}$ & 163.5 & 124.6 & 160.4 & 128.1 & TBD & 103.1 & 75.4 & TBD & TBD & TBD \\
\hline $\begin{array}{l}\text { Surface Area } \\
\left(\mathrm{m}^{2}\right)\end{array}$ & 195.4 & 293.0 & 195.4 & 293.0 & $\begin{array}{l}293 . \\
0\end{array}$ & 193.8 & 237.9 & TBD & TBD & 211.7 \\
\hline \# crew flights & 3 & 3 & 3 & 3 & 2 & 2 & 2 & TBD & TBD & 1 \\
\hline \# cargo flights & 1 & 1 & 1 & 1 & 1 & 1 & 1 & TBD & TBD & 1 \\
\hline
\end{tabular}

Table 4. Data inputs for Lunar Surface Habitat Configuration Assessment. 


\section{Assessment Evaluation}

The data in Table 4 was assessed based on the information provided in Table 2, and the results are shown in the graph in Figure 3. The graph represents 4 assessments (S1, S2, S3, S4) for a multi-element aluminum lithium habitat configuration and Table 5 explains the FOM categories along the $\mathrm{x}$-axis. The parameter for the habitat dimensions was driven by the expectation of a 10 meter shroud. This is one sample of the method utilized to produce lunar habitat desired features, operational considerations, and risks to drive habitat requirements.

\begin{tabular}{|c|c|}
\hline X-axis & FOM Description \\
\hline 1 & Habitat Dimensions \\
\hline 2 & Volume $\left(\mathrm{m}^{3}\right)$ @ IOC \\
\hline 3 & Habitable volume $\left(\mathrm{m}^{3}\right)$ \\
\hline 4 & Volume $\left(\mathrm{m}^{3}\right) /$ Crew \\
\hline 5 & Mass $(\mathrm{kg}) /$ landing \\
\hline 6 & Mass at IOC \\
\hline 7 & Mass $(\mathrm{kg}) /$ Volume $\left(\mathrm{m}^{3}\right)$ \\
\hline
\end{tabular}

Table 5. Data Points for Figure 2.

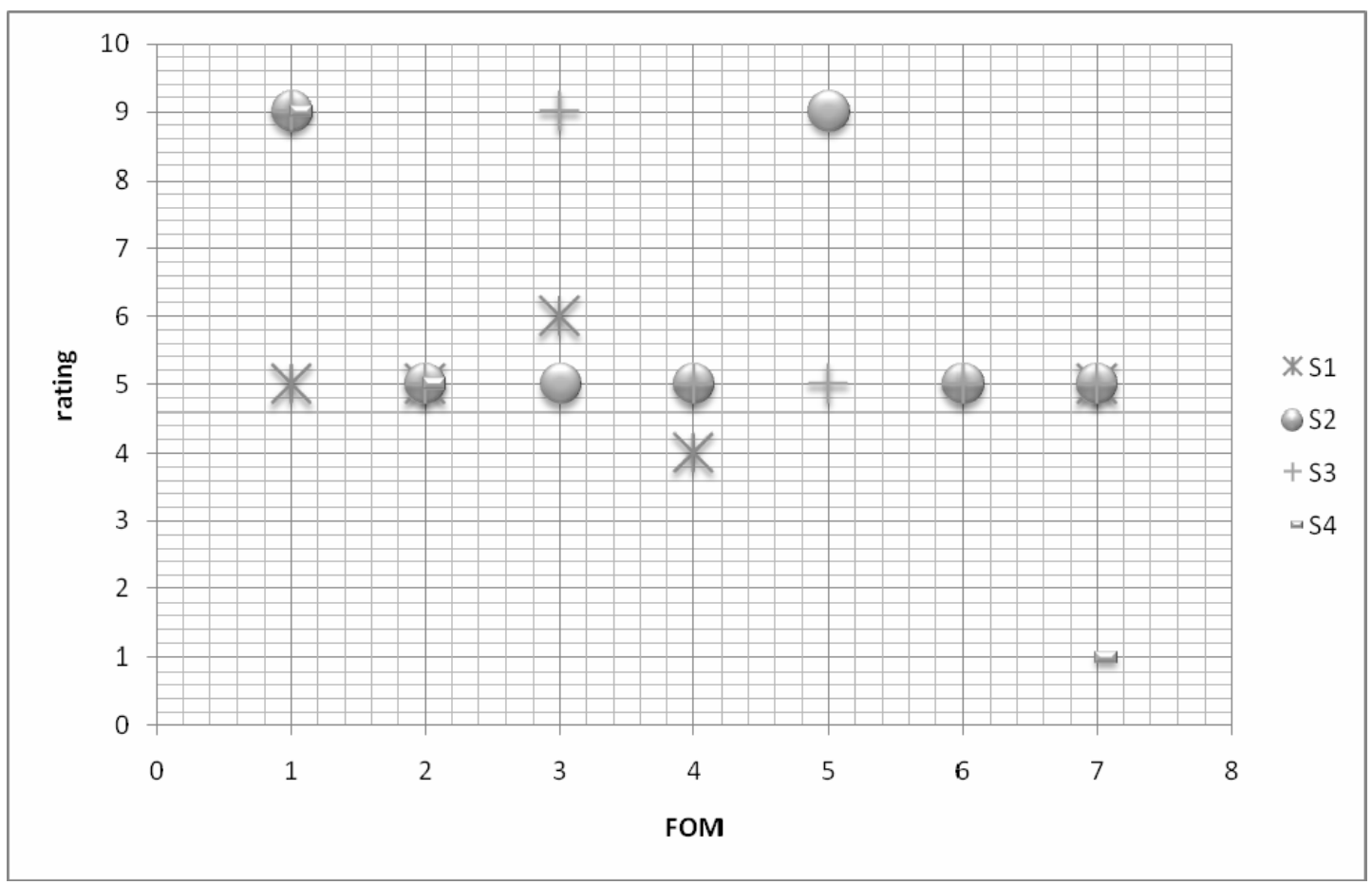

Figure 2. Graph of Assessments for the 4-3m x 3m x 5 Al-Lithium mini-hab Habitat Configuration. 


\section{Desired Features}

Through the several iteration of this assessment, several desired features became apparent. The need for a habitat to be close to the lunar surface for ease of access to the lunar surface during EVA operations emerged. Based on the mass parameters, the desire to have dual functionality among the key functional area not only could provided added capability but in turn provided a higher fault tolerance factor during off nominal conditions.

Protection from the lunar environmental is paramount for a successful mission. As a result of this assessment, minimum surface operations and early integration was desired. Whether integrated into the habitat or provided by other resources, the ability to access the exterior of the habitat for easy of accomplishing the environmental protection strategy was desired.

\section{Observations}

This assessment, for the most part, was subjective due to the limited data available and limited research on lunar surface habitation. The design of this assessment provided a means to refine possible habitat figure of merit for future efforts. In addition, the assessment resulted in the initiation of other key trades and assessments to derive lunar habitat requirements.

This initial assessment presented the need to better understand the technology readiness for the various systems. Higher percentage of new technology required to develop necessary materials could pose higher risks to actual delivery and costs. Additional effort to recognize the technology needs and gaps is required for a comprehensive understanding of the technology readiness levels.

\section{Conclusion}

Many challenges transpired due to minimal or, in some cases, no previous data points to determine the optimal solutions for lunar surface habitability, but overall this assessment provided valuable insight. For example, understanding minimum volume requirements for habitably was a challenge with no prior studies or evaluation for basis of analysis. As a result, a volumetric assessment was performed by the habitation focus element and enhanced, recommended requirements were established. This recommendation still needs validation through concept development initiatives.

In theory, the assessment was designed to derive habitat requirements, potential technology development needs and identify risks associated with living and working on the lunar surface. Although the results were more subjective opposed to objective, the assessment provided insightful observations for further assessments and trade studies of lunar surface habitats. 